\title{
KAJIAN KEBUTUHAN LAMPU LALU LINTAS PADA SIMPANG 6 KUTABLANG LHOKSEUMAWE
}

\author{
Wesli $^{1)}$, Said Jalalul Akbar ${ }^{2)}$ \\ 1), 2) Jurusan Teknik Sipil, Fakultas Teknik, Universitas Malikussaleh \\ email: ${ }^{1)}$ ir_wesli@yahoo.co.id; ${ }^{21}$ jaakidani@gmail.com
}

\begin{abstract}
Abstrak
Simpang Kutablang merupakan simpang berlengan 6 dengan beban lalu lintas yang bertambah dari waktu ke waktu. Untuk meningkatkan tingkat pelayanannya perlu suatu kajian terhadap kebutuhan lampu lalu lintas baik pada saat ini maupun prediksi ke depannya. Kajian ini dilakukan berdasarkan volume kendaraan dan kecepatan kenderaan. Analisis waktu siklus lampu lalu lintas dilakukan dengan menggunakan metode Webster. Hasil kajian menggambarkan bahwa volume lalu lintas tertinggi terjadi pada hari senin sebesar 2062,77 smp/jam dan kecepatan rata-rata kendaraan yaitu sebesar $24,85 \mathrm{~km} / \mathrm{jam}$.Berdasarkan hal tersebut dapat dinyatakan bahwa dari variabel volume kenderaan belum membutuhkan lampu lalu lintas karena menurut MKJI (1997) kapasitas dasar penentuan kebutuhan lampu lalu lintas adalah apabila volume kenderaan minimal sebesar 2900 smp/jam. Dari variabel kecepatan kenderaan dapat dinyatakan bahwa simpang Kutablang sudah membutuhkan lampu lalu lintas karena menurut MKJI (1997) kecepatan minimum terhadap kebutuhan lampu lalu lintas adalah sebesar $28 \mathrm{~km} / \mathrm{jam}$. Dari hasil forecasting (prediksi) berdasarkan volume kenderaan dapat dinyatakan bahwa kebutuhan lampu lalu lintas ke depannya terjadi pada tahun 2016 dengan waktu siklus sebesar 118 detik untuk jam puncak pagi, 104 detik untuk jam puncak siang dan 115 detik untuk jam puncak sore. Kesimpulan hasil kajian menunjukkan bahwa Simpang 6 Kutablang Lhokseumawe pada saat ini tahun 2013 belum diperlukan lampu lalu lintas, kebutuhan tersebut diperkirakan akan terjadi pada tahun 2016
\end{abstract}

Kata kunci: Lampu Lalu Lintas, kecepatan, volume kendaraan, forecasting.

\section{Pendahuluan}

Simpang merupakan bagian dari suatu jaringan jalan sebagai daerah yang kritis tempat titik konflik dan tempat kemacetan karena bertemunya dua ruas jalan atau lebih sehingga membutuhkan pengaturan guna menghindari dan meminimalisir terjadinya konflik. Permasalahan lalu lintas yang terjadi pada persimpangan adalah meningkatnya volume kendaraan yang mempengaruhi kapasitas persimpangan sehingga tingkat kinerja lalu lintas persimpangan akan menurun dan bagi pengguna jalan akan memperlamabat waktu perjalanan.

Simpang Kutablang mempunyai enam lengan persimpangan yang dibentuk oleh jalan Merdeka Barat, jalan Merdeka Timur, jalan Kenari dan jalan Air Bersih. Simpang tersebut merupakan jalur utama untuk masuk dan keluar kota Lhokseumawe. Pergerakan kendaraan kondisi eksisting di simpang tersebut adalah kendaraan dapat bergerak dari jalan Merdeka Barat lurus ke arah kota, berbelok kiri ke jalan Kenari dan ke jalan Air Bersih, dan berbelok ke kanan ke jalan Merdeka Timur. Kendaraan dari jalan Merdeka Timur dapat bergerak lurus ke arah Cunda, berbelok kiri ke jalan Rumoeh Alue, dan berbelok ke kanan ke 
jalan Merdeka Barat, jalan Kenari dan jalan Air Bersih. Kendaraan dari jalan Kenari dapat bergerak lurus ke arah jalan Merdeka Barat, berbelok ke kiri ke jalan Air Bersih, dan berbelok ke kanan ke jalan Merdeka Timur melalui jalan Merdeka Barat. Kendaraan dari jalan Air Bersih hanya dapat bergerak ke kiri ke jalan Merdeka Barat seperti diperlihatkan pada Gambar 1.

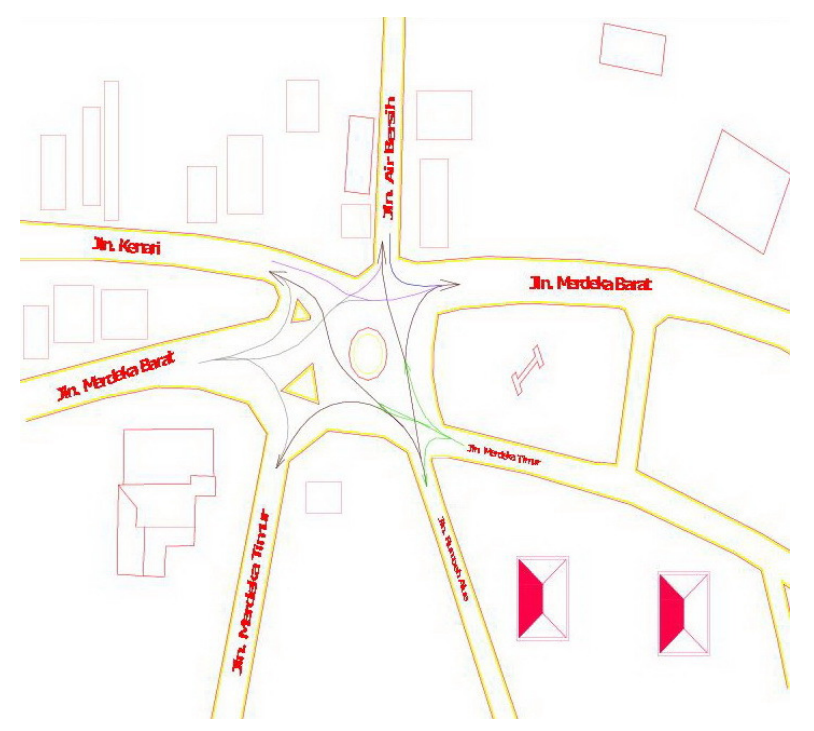

Gambar 1.1 Lokasi Penelitian dan Arah Pergerakan Kendaraan

Beban lalu lintas yang meningkat dari waktu ke waktu menyebabkan Simpang Kutablang sering terjadi kemacetan pada kondisi tertentu sehingga tingkat pelayanannya menjadi semakin rendah, hal ini disebabkan karena pada simpang tersebut belum dipasang lampu lalu lintas (traffic light). Untuk meningkatkan tingkat pelayanannya perlu suatu kajian terhadap kebutuhan lampu lalu lintas baik pada saat ini maupun prediksi ke depannya

Tujuan penelitian untuk mengetahui apakah simpang Kutablang pada saat ini sudah membutuhkan lampu lalu lintas (traffic light) dan meninjau efisiensi dan efektivitas perencanaan lampu lalu lintas sehingga dapat direncanakan waktu siklus lalu lintas persimpangan tersebut berdasarkan hubungan volume lalu lintas dan kecepatan yang diperlukan untuk melewati persimpangan. Kajian ini dilakukan berdasarkan volume kendaraan dan kecepatan kenderaan. Analisis waktu siklus lampu lalu lintas dilakukan dengan menggunakan metode Webster

\section{Tinjauan Kepustakaan}

\subsection{Persimpangan}

Menurut Saodang (2004), persimpangan merupakan pertemuan dua atau lebih ruas jalan, bergabung, berpotongan, atau bersilangan. Lalu lintas pada masing-masing kaki persimpangan secara bersama-sama menggunakan ruas jalan pada persimpangan. Persimpangan merupakan faktor yang paling penting dalam menentukan kapasitas dan waktu perjalanan pada suatu jaringan jalan. Perencanaan persimpangan dilakukan untuk mengendalikan kecepatan kendaraan yang melalui persimpangan serta mengendalikan, mengurangi, atau menghilangkan gerakan yang berpotongan. Berdasarkan geometrik persimpangan 
jalan terbagi atas dua kategori utama yaitu persimpangan sebidang (atgrade intersection) dan persimpangan tidak sebidang (inter change). Dari sifat dan tujuan pergerakan didaerah persimpangan, dikenal beberapa bentuk alih gerak (manuver) yaitu :

1. Diverging (memisah) adalah peristiwa memisahnya kendaraan dari suatu arus yang sama ke jalur yang lain.

2. Merging (bergabung) adalah peristiwa bergabungnya kendaraan dari satu jalur ke jalur yang lain.

3. Crossing (berpotongan) adalah peristiwa dimana arus kendaraan dari satu jalur ke jalur yang lain pada persimpangan saling berpotongan.

4. Weaving (menyilang) adalah peristiwa pertemuan dua arus lalu lintas atau lebih yang berjalan menurut arah yang sama sepanjang suatu lintasan di jalan raya tanpa bantuan rambu lalu lintas.

\subsection{Lampu lalu lintas}

Menurut Saodang (2004), lampu lalu lintas merupakan alat pengatur lalu lintas yang mempunyai fungsi utama sebagai pengatur hak berjalan pergerakan lalu lintas (termasuk pejalan kaki) secara bergantian di pertemuan jalan. Lampu lalu lintas berfungsi untuk mengurangi adanya konflik antara berbagai pergerakan lalu lintas dengan cara memisahkan pergerakan-pergerakan tersebut dari segi ruang dan waktu. Secara umum lampu lalu lintas dipasang pada suatu persimpangan berdasarkan alasan spesifik:

1. Untuk meningkatkan keamanan sistem secara keseluruhan.

2. Untuk mengurangi waktu tempuh rata-rata di sebuah persimpangan, sehingga meningkatkan kapasitas.

3. Untuk menyeimbangkan kualitas pelayanan di seluruh aliran lalu lintas.

\subsection{Metode Webster}

Webster menggunakan pengamatan lapangan yang ekstensif dan simulasi komputer untuk menghasilkan prosedur yang sangat baik dalam mendesain lampu lalu lintas. Asumsi dasar dalam pekerjaan Webster adalah bahwa kedatangan kendaraan terjadi secara acak. Webster mengembangkan persamaan klasik untuk menghitung penundaan rata-rata per kendaraan ketika mendekati persimpangan, dan juga menurunkan sebuah persamaan untuk memperoleh waktu siklus optimum yang menghasilkan penundaan kendaraan minimum. Webster menggunakan terminologi yang membutuhkan beberapa faktor dasar untuk menentukan perhitungan yang menggunakan metode Webster. Faktor yang dibutuhkan untuk menggunakan metode Webster adalah:

1. Arus jenuh

Menurut Khisty dan Lall (2005), arus jenuh adalah arus yang akan diperoleh seandainya terdapat antrian kendaraan yang kontinu dan seandainya kendaraan diberi waktu hijau 100\%. Arus jenuh dapat digambarkan sebagai ketika kendaraan melewati garis berhenti disebuah persimpangan, ketika lampu hijau mulai menyala, kendaraan membutuhkan waktu beberapa saat untuk mulai bergerak dan melakukan percepatan menuju kecepatan normal, tetapi setelah beberapa detik, antrian kendaraan mulai bergerak pada kecepatan yang relatif konstan. Arus jenuh biasanya dinyatakan dalam kendaraan per jam waktu hijau. 
2. Volume kendaraan yang masuk (qs)

Jumlah kendaran yang masuk pada suatu ruas persimpangan dalam satu satuan batas waktu. Yang sudah dikalikan dengan koefisien masing-masing sesuai dengan jenis kendaraan yang melewati ruas simpang tersebut.

3. Waktu hilang

Selisih antara waktu hijau efektif dengan periode gabungan hijau dan kuning.

\subsection{Volume lalu lintas}

Menurut Sukirman, S (1999), sebagai pengukur jumlah dari arus lalu lintas digunakan volume lalu lintas.Volume lalu lintas menunjukkan jumlah kendaraan yang melintasi satu titik pengamatan dalam satu satuan waktu. Dalam volume lalu lintas yang tinggi membutuhkan lebar perkerasan jalan yang lebih besar, sehingga terciptanya kenyamanan dan keamanan. Untuk lalu lintas harian rata-rata volumenya diambil dalam satu hari kemudian dari cara memperoleh data tersebut dikenal dua jenis lalu lintas yaitu: lalu lintas Harian Rata-Rata Tahunan (LHRT) dan lalu lintas Harian Rata-Rata (LHR). Dengan demikian mengingat biaya yang diperlukan dan membandingkan dengan ketelitian yang dicapai serta tak semua tempat di Indonesia mempunyai data volume lalu lintas selama setahun, maka untuk kondisi tersebut dapat pula digunakan setahun "lalu lintas harian rata-rata (LHR)" maka untuk menghitung LHR dengan persamaan :

$$
L H R=\frac{N}{T}
$$

di mana :

LHR = Lalu lintas harian rata-rata (kend/jam)

$\mathrm{N} \quad=$ Volume lalu lintas selama pengamatan (kendaraan)

$\mathrm{T} \quad=$ Lamanya pengamatan $(\mathrm{jam})$

Berdasarkan MKJI (1997), untuk kapasitas dasar volume kendaraan adalah sebesar $2900 \mathrm{smp} / \mathrm{jam}$. Nilai tersebut merupakan penentu diperlukan atau tidaknya pemasangan lampu lalu lintas di suatu persimpangan. Suatu arus lalu lintas dapat dikatakan lancar apabila arus lalu lintas tersebut dapat melewati suatu ruas jalan atau simpang tanpa mengalami hambatan atau gangguan, sehingga pada jaringan jalan tersebut tidak mengalami masalah lalu lintas. Masalah lalu lintas yang timbul di jalan raya dapat disebabkan oleh banyak faktor yang dapat mempengaruhi efisiensi serta keamanan pengguna jalan. Faktor-faktor yang dapat menyebabkan masalah tersebut yaitu :

1. Faktor jalan (fisik)

2. Faktor lalu lintas (kendaraan)

3. Faktor manusia (pengemudi dan pengguna jalan)

4. Fasilitas jalan

\subsection{Kecepatan}

Kecepatan didefinisikan sebagai laju dari suatu pergerakan kendaraan dihitung dalam jarak per satuan waktu. Dalam pergerakan arus lalu lintas, tiap kendaraan berjalan pada kecepatan yang berbeda. Dengan demikian dalam arus lalu lintas tidak dikenal karakteristik kecepatan tunggal, akan tetapi lebih dikenal sebagai distribusi dari kecepatan tersebut. Dalam perhitungan, kecepatan rata-rata dapat dibedakan menjadi dua jenis yakni : 
1. Time Mean Speed (TMS), dapat didefinisikan sebagai kecepatan rata-rata dari seluruh kendaraan yang melewati suatu titik pada jalan selama periode waktu tertentu.

2. Space Mean Speed (SPS), yakni kecepatan rata-rata dari seluruh kendaraan yang menempati suatu penggal jalan selama periode waktu tertentu.

Menurut Alamsyah (2008), kecepatan menentukan jarak yang dijalani pengemudi kendaraan dalam waktu tertentu. Pemakai jalan dapat menaikkan kecepatan untuk memperpendek waktu perjalanan, atau memperpanjang jarak perjalanan. Nilai perubahan kecepatan adalah mendasar, tidak hanya untuk berangkat dan berhenti tetapi untuk seluruh arus lalu lintas yang dilalui. Berdasarkan MKJI (1997), pada simpang enam lengan, untuk kecepatan rata-rata kendaraan $<28 \mathrm{~km} / \mathrm{jam}$, diharuskan untuk menggunakan lampu lalu lintas karena kecepatan kendaraan $<28 \mathrm{~km} /$ jam berarti kendaraan mengalami perlambatan pada saat di persimpangan tersebut. Ketentuan ini merupakan salah satu syarat selain volume kendaraan untuk penentuan diperlukannya pemasangan lampu lalu lintas di persimpangan. Kecepatan adalah sebagai rasio jarak yang dijalani dan waktu perjalanan. Hubungan yang ada adalah :

$$
V=\frac{s}{t}
$$

di mana :

$$
\begin{aligned}
& \mathrm{V}=\operatorname{kecepatan}(\mathrm{m} / \mathrm{s}) \\
& \mathrm{s}=\text { jarak perjalanan }(\mathrm{m}) \\
& \mathrm{t}=\text { waktu perjalanan }(\mathrm{s})
\end{aligned}
$$

\subsection{Forecasting (Perkiraan)}

Perkiraan (Forecasting) adalah suatu kegiatan yang memperkirakan apa yang akan terjadi pada masa mendatang (Kemal, H, 2004). Peramalan diperlukan karena adanya perbedaan waktu antara keadaan akan dibutuhkannya suatu kebijakan baru. Apabila perbedaan waktu tersebut panjang, maka para peran perkiraan menjadi penting dan sangat dibutuhkan, terutama dalam penentuan kapan terjadi suatu peristiwa sehingga dapat di persiapkan tindakan-tindakan yang diperlukan. Kegunaan dari suatu perkiraan dapat dilihat pada saat pengambilan keputusan. Keputusan yang baik adalah keputusan yang didasarkan oleh pertimbangan apa yang akan terjadi saat keputusan tersebut dilakukan. Apabila keputusan yang diambil kurang tepat sebaiknya keputusan tersebut tidak dilaksanakan. Oleh karena masalah pengambilan keputusan merupakan masalah yang dihadapi maka perkiraan juga merupakan masalah yang harus dihadapi, karena perkiraan berkaitan erat dengan pengambilan suatu keputusan. Penentuan forecasting tahun tersebut dapat ditentukan dengan menggunakan persamaan :

$$
P_{n}=P_{0}+(1+r)^{n}
$$

di mana :

Pn = jumlah volume kendaraan pada tahun ke n;

Po = jumlah volume kendaraan pada tahun dasar;

$\mathrm{r}$ = laju volume kendaraan;

$\mathrm{n}=$ jumlah interval 


\section{Metode Penelitian}

\subsection{Pengumpulan Data}

Pengambilan data primer dilakukan melalui survey volume lalu lintas, geometrik, dan kecepatan. Pengukuran geometrik simpang di lakukan dengan mencatat jumlah lajur dan arah, menentukan pendekat dengan menggunakan meteran serta alat tulis dan formulir penelitian untuk melakukan pencatatan. Survey arus pada masing-masing pendekat dengan menghitung jumlah kendaraan yang lewat. Survey tersebut dilakukan dengan menggunakan counter digital, alat tulis dan formulir penelitian. Pencatatan arus lalu lintas pada lokasi peninjauan menggunakan counter digital yang digunakan oleh masing-masing enomerator pada tiap simpang. Pengamatan kecepatan kendaraan saat memasuki persimpangan dilakukan pada masing-masing jam puncak yang telah ditentukan selama 1 jam selama 3 hari dengan menggunakan stopwatch, alat tulis, dan formulir penelitian. Pengamatan volume lalu lintas pada masing-masing ruas dilakukan pada masing-masing jam puncak yang telah ditentukan selama 1 jam selama 3 hari dengan menggunakan counter digital, alat tulis, dan formulir penelitian.

\subsection{Analisa dan Pengolahan Data}

Berdasarkan hasil analisa pada evaluasi operasional lalu lintas pada simpang tak bersinyal tersebut diperoleh volume kendaraan sebesar 1979,87 smp/jam dan derajat kejenuhan (DS) sebesar 0,95. Hal ini sudah lebih besar dari 0,85 melampaui batas derajat kejenuhan maksimum menurut MKJI 1997, sehingga persimpangan tersebut sudah jenuh untuk menampung besarnya arus kendaraan yang melewatinya. Sedangkan tundaan simpang yang diperoleh adalah 17,11 det/smp, angka ini sudah melewati dari $15 \mathrm{det} / \mathrm{smp}$ yang merupakan batas tundaan maksimum menurut MKJI 1997. Upaya untuk mengurangi konflik lalu lintas di persimpangan diperlukan manajemen lalu lintas dengan pengaturan menggunakan traffic light (lampu sinyal lalu lintas).

\section{Hasil dan Pembahasan}

\subsection{Kondisi geometrik persimpangan}

Hasil pengukuran geometrik jalan diperoleh dari pengukuran langsung di lapangan. Pada persimpangan ini, jumlah pendekat sebanyak 5 pendekat dengan lebar eksisting pendekat simpang yang bervariasi. Keadaan geometrik persimpangan yang tidak simetris dan jumlah lengan persimpangan yang banyak ini menjadi faktor utama pada persimpangan, yang menyebabkan banyak terjadinya titik konflik. Jalan Merdeka Barat terdiri dari dua lajur dan satu arah dengan lebar perkerasan 8,5 meter. Jalan Kenari terdiri dari dua lajur dan dua arah dengan lebar perkerasan 7,5 meter. Jalan Merdeka Timur terdiri dari dua lajur dan satu arah dengan perkerasan 7 meter. Jalan Air Bersih terdiri dari satu lajur dan dua arah dengan lebar perkerasan 5,5 meter.

\subsection{Volume lalu lintas}

Volume lalu lintas 3 hari yaitu hari Senin, Rabu dan Kamis dikonversikan ke dalam satuan mobil penumpang (smp) masing-masing kendaraan didapatkan jumlah LHR kendaraan seperti diperlihatkan pada Tabel 1. 


\begin{tabular}{|c|c|}
\hline Jam puncak & $\begin{array}{c}\text { Total } \\
\text { (smp) }\end{array}$ \\
\hline $07.15-08.15$ & $1.556,9$ \\
\hline $12.00-13.00$ & $1.353,2$ \\
\hline $16.30-17.30$ & $1.446,5$ \\
\hline
\end{tabular}

Tabel 1 Volume Kendaraan Pada Tiap Jam Puncak

Fluktuasi volume lalu lintas selama pengamatan seperti diperlihatkan pada Gambar 2

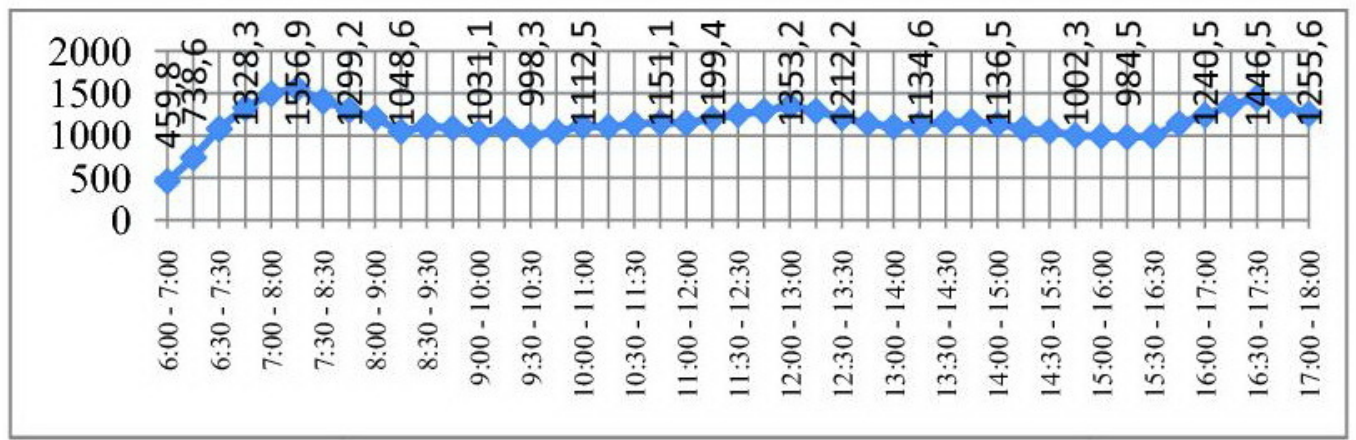

\section{Gambar 2 Grafik Fluktuasi Volume Lalu Lintas}

\subsection{Kecepatan}

Kecepatan pada jam puncak pagi saat mendekati persimpangan dari ruas jalan Merdeka Barat adalah 31,89 km/jam dan dari ruas jalan Merdeka Timur adalah 30,96 km/jam. Kecepatan pada jam puncak siang saat mendekati persimpangan dari ruas jalan Merdeka Barat adalah 31,04 km/jam dan dari ruas jalan Merdeka Timur adalah 32,59 km/jam. Sedangkan kecepatan pada jam puncak sore saat mendekati persimpangan dari ruas jalan Merdeka Barat adalah $31,44 \mathrm{~km} / \mathrm{jam}$ dan dari ruas jalan Merdeka Timur adalah 29,12 km/jam. Untuk kecepatan pada jam puncak pagi saat melewati persimpangan dari ruas jalan Merdeka Barat adalah 31,93 km/jam dan dari ruas jalan Merdeka Timur adalah $14,48 \mathrm{~km} / \mathrm{jam}$. Kecepatan pada jam puncak siang saat melewati persimpangan dari ruas jalan Merdeka Barat adalah 22,97 km/jam dan dari ruas jalan Merdeka Timur adalah $17,10 \mathrm{~km} / \mathrm{jam}$, sedangkan kecepatan pada jam puncak sore saat melewati persimpangan dari ruas jalan Merdeka Barat adalah 22,77 km/jam dan dari ruas jalan Merdeka Timur adalah 15,86 km/jam. Kecepatan rata-rata kendaraan saat melewati simpang adalah $24,85 \mathrm{~km} / \mathrm{jam}$.

\subsection{Forecasting (perkiraan)}

Pada penentuan kebutuhan lampu lalu lintas didapat bahwa diantara kedua faktor yaitu volume kendaraan dan kecepatan, hanya faktor kecepatan yang mendukung untuk dipasangnya lampu lalu lintas tersebut sedangkan berdasarkan volume, belum memenuhi syarat untuk diperlukannya lampu lalu lintas itu saat ini. Oleh karena itu, dilakukan forecasting (perkiraan). Forecasting yang dilakukan meliputi penentuan tahun dibutuhkannya lampu lalu lintas, volume kendaraan dan kecepatan kendaraan. Forecasting penentuan tahun dibutuhkannya 
lampu lalu lintas didapat hasil 2093,42 smp/jam pada perkiraan tahun 2016. Hasil tersebut lebih besar dari 2900 smp/jam yang merupakan nilai syarat volume kendaraan untuk menentukan diperlukannya lampu lalu lintas.

\subsection{Perhitungan waktu siklus dengan metode webster}

Penentuan perhitungan waktu siklus dengan metode webster meliputi penentuan panjang periode kuning, waktu hilang karena antrian kendaraan, waktu hilang kendaraan terakhir menyebrangi persimpangan, jumlah waktu hilang, jumlah waktu hilang tiap siklus lampu, penentuan panjang siklus lampu lalu lintas, penentuan waktu hijau efektif total, penentuan panjang periode kuning dan hijau untuk masing-masing fase dan penentuan panjang periode merah untuk masing-masing fase. Penentuan semua waktu siklus tersebut menggunakan data hasil perhitungan forecasting 2016.

Satu fase pada umumnya terdiri dari dua tanda indikasi yaitu warna hijau dan warna kuning. Pada persimpangan ini direncanakan 2 fase karena jika dipakai 3 fase diperoleh panjang waktu siklus lebih besar dari pada panjang siklus maksimum yaitu $\mathrm{C}>130$. Panjang periode kuning pada setiap jam puncak yaitu jam puncak pagi, siang dan sore diperoleh waktu 3 detik. Panjang periode kuning berfungsi untuk memberikan peringatan pada kendaraan yang mendekati persimpangan pada saat berwarna hijau. Peringatan tersebut berarti dengan warna kuning lampu akan merah dan giliran berjalan akan diberikan pada aliran lalu lintas dari arah lain. Biasanya kendaraan yang mendekati persimpangan pada saat lampu hijau, akan melaju dengan kecepatan tinggi karena mengharapkan dapat terus memasuki dan melewati persimpangan. Waktu hilang karena antrian kendaraan (k1) menurut Webster yang dikutip dari buku karangan Bukhari, dkk (1997) adalah 3,7 detik. Nilai ini merupakan nilai konstanta. Waktu hilang karena antrian kendaraan ini adalah waktu yang hilang saat kendaraan hendak bergerak meninggalkan lampu hijau. Waktu hilang kendaraan terakhir menyeberangi persimpangan pada masing-masing kaki persimpangan adalah sebesar 2 detik. Jumlah waktu hilang tiap siklus lampu adalah 12 detik. Jumlah waktu hilang tiap siklus lampu merupakan hasil penjumlahan dari jumlah waktu hilang pada masing-masing kaki persimpangan. Perhitungan waktu siklus dengan menggunakan nilai waktu hilang karena antrian (k1) adalah untuk jam puncak sore. Panjang waktu hijau efektif total untuk jam puncak siang adalah sebesar 92 detik. Waktu hijau efektif total dihasilkan dari panjang siklus lampu lalu lintas dikurang dengan jumlah waktu hilang tiap siklus lampu. Waktu hijau efektif total ini merupakan nilai yang digunakan untuk mencari nilai panjang periode hijau dan kuning untuk masing-masing fase. Perhitungan panjang waktu hijau efektif total pada jam puncak siang 92 detik. Perhitungan panjang periode hijau dan kuning untuk masing-masing fase adalah untuk jam puncak pagi yaitu 58 detik Panjang periode merah untuk masing-masing fase. Perhitungan panjang periode merah untuk masing-masing fase berikut ini adalah untuk jam puncak pagi. sebesar 59 detik

\subsection{Sistem pengaturan lampu lalu lintas}

Jenis sistem pengaturan lampu lalu lintas di Lhokseumawe menggunakan sistem pretime signal yaitu lampu dengan waktu tetap. Waktu siklus yang telah 
ditentukan dengan menggunakan metode Webster kemudian digunakan nilai yang terbesar untuk masing-masing fase pada simpang. Didapatkan bahwa untuk fase I (jalan Merdeka Timur), panjang periode merahnya yaitu 59 detik, panjang periode kuning yaitu 3 detik dan panjang periode hijau yaitu 55 detik. Sedangkan untuk fase II (jalan Merdeka Barat), didapatkan nilai panjang periode merahnya yaitu 60 detik, panjang periode kuning yaitu 3 detik dan panjang periode hijau yaitu 56 detik.

\section{Kesimpulan dan Saran}

Hasil penelitian dilapangan, pengolahan data dan perhitungan dapat diambil beberapa kesimpulan dan beberapa saran.

\subsection{Kesimpulan}

Berdasarkan dari hasil penelitian dan pembahasan yang telah dilakukan maka dapat diambil beberapa kesimpulan sebagai berikut :

1. Pada kondisi eksisting, berdasarkan faktor penentuan kebutuhan lampu lalu lintas berupa yaitu kecepatan dan volume kendaraan, hanya faktor kecepatan kendaraan yang mendukung pemasangan lampu lalu lintas. Sedangkan faktor volume kendaraan tidak mendukung sehingga dapat disimpilkan bahwa kondisi eksisting belum diperlukan pengaturan lampu lalu lintas.

2. Dari hasil proyeksi data volume lalu lintas melali forecasting pemasangan kebutuhan lampu lalu lintas diperkirakan pada tahun 2016.

3. Kebutuhan lampu lalu lintas pada tahun 2016 dipasang pada dua ruas jalan yaitu jalan Merdeka Timur dan jalan Merdeka Barat menggunakan dua fase.

4. Panjang waktu siklus lampu lalu lintas dengan menggunakan metode Webster dan menggunakan nilai forecasting tahun 2016, diperoleh 118 detik untuk jam puncak pagi (07:15 - 08:15), 104 detik untuk jam puncak siang (12.00-13.00), dan 115 detik untuk jam puncak sore (16:30 - 17:30). Ketiga nilai masingmasing jam puncak ini kemudian disesuaikan dengan sistem pengaturan lampu lalu lintas yang menggunakan sistem pretime signal.

\subsection{Saran}

Berdasarkan dari hasil penelitian dan kesimpulan di atas dapat diberikan saran-saran sebagai rekomendasi antara lain :

1. Volume lalu lintas yang setiap tahunnya terus bertambah menjadi permasalahan terbesar bagi pemerintah daerah setempat. Keadaan jalan yang tidak mampu lagi menampung arus lalu lintas mengharuskan pemerintah setempat melakukan tindakan yang tepat yaitu dengan mengatur manajemen lalu lintas, seperti perencanaan lampu lalu lintas (traffic light) dan pengaturan arus lalu lintas pada jam-jam puncak. Walaupun saat ini simpang tersebut belum memerlukan lampu lalu lintas, namun akan diperlukan untuk tahun 2016.

2. Diharapkan kepada pemerintah setempat agar pulau-pulau kecil yang ada di simpang Kutablang tersebut lebih baik tidak digunakan. Lebih baik bila lampu lalu lintas telah dipasang, cukup menggunakan satu tugu di tengah-tengah simpang tersebut. Serta sebaiknya di jalan Merdeka Barat sebelum simpang Kutablang, dibangun sebuah halte agar kendaraan umum tidak menurunkan penumpang di sembarang tempat. 
3. Disarankan agar Polantas dan petugas LLAJR bersiaga di simpang Kutablang tersebut pada jam-jam puncak dikarenakan sikap pengendara yang tidak memperhitungkan resiko dan sering melanggar peraturan.

\section{Daftar Kepustakaan}

1. Ansyori Alamsyah, Alik, 2008, Rekayasa Lalu Lintas, Umm Press, Malang.

2. Kemal, H, 2004, Perancangan Manajemen Lalu Lintas Persimpangan Gandapura, http://www.google.com, Theses. Diunduh tanggal 10 Januari 2013.

3. Khisty, C. Jotin dan Lall, B. Kent, 2003, Dasar-dasar Rekayas Transportasi, Erlangga, Jakarta

4. Direktorat Jenderal Bina Marga, 1997, Manual Kapasitas Jalan Indonesia, Departemen Pekerjaan Umum, Indonesia.

5. Saodang, Hamirhan, 2004, Konstruksi Jalan Raya, Nova, Bandung

6. Sukirman, Silvia, 1999, Dasar-Dasar Perencanaan Geometrik Jalan, Nova, Bandung. 